\title{
Dual Systems of Family Law: A Comment
}

\section{Walter $O$. Weyrauch*}

$\mathrm{M}$ UCH IEGAL REASONING seems to follow the model of a litigious, adversary context. The method has its proven merits as an intellectual tool facilitating discussion, even though at times issues are dichotomized and differences of opinion unduly stressed. While adopting this method, I shall try to provide a synthesis.

The article by Professors Thomas P. Lewis and Robert J. Levy, Family Law and Welfare Policies-The Case for "Dual Systems," published in this symposium, ${ }^{1}$ is difficult to evaluate for a reason that illustrates a recurrent problem of legal scholarship. The article was prompted by Professor Jacobus tenBroek's major effort, California's Dual System of Family Law: Its Origin, Development, and Present Status, which appeared in three installments in the Stanford Law Review. ${ }^{2}$ As an inevitable consequence the comments of Lewis and Levy cannot be fully appreciated unless tenBroek's work is closely read, followed by a second reading of the Lewis and Levy paper. Most readers cannot be expected to engage in this circular process.

Ideally authors of critical essays should assume that only rarely will the original source be consulted in its totality. Perhaps an individual page reference will be checked. Even this may not be done by the reader, and the argumentation and comments of the critic are likely to be taken at face value. The critic is vested with a factual power over the subject matter, a situation that may inadvertently result in injustice. This imposes a responsibility on him, related to what may loosely be called "academic due process," to present his views in a fashion that incorporates the reasoning contained in the original source. Since incorporation by mere reference is not satisfactory, the original reasoning must somehow be made part of the critical essay, a very difficult task requiring close identifications. If the approach of the critic is essentially negative, he may face a contradictory, perhaps an impossible task. This is his dilemma.

Professors Lewis and Levy have made a diligent effort to do justice to Professor tenBroek's work. In an effort to enunciate his thoughts, they have inserted large quotes. ${ }^{3}$ Perhaps even this is not quite satisfactory.

*Dr. Jur., 1951, University of Frankfort on the Main, Germany ; LL.B., 1955, Georgetown University; LL.M., 1956, Harvard University; J.S.D., 1962, Yale University. Professor of Law, on leave, University of Florida, Gainesville; Visiting Research Lawyer, University of California, Berkeley, Space Sciences Laboratory, Social Sciences Project.

154 CaIm. L. Rev. 748 (1966).

2 (pts. 1, 2), 16 Stan. L. Rev. 257, 900 (1964); (pt. 3), 17 Stan. L. Rev. 614 (1965) [hereinafter cited as tenBroek, with appropriate volume and page].

${ }^{3}$ Lewis \& Levy, Family Law and Welfare Policies-The Case for "Dual Systems," 54 CALIF. L. REv. 751-52, 756-57 (1966). 
The excerpts are taken from summarizing or concluding paragraphs, where tenBroek expresses his thoughts on a somewhat higher level of generalization. ${ }^{4}$ Frequently the excerpts have an idealistic and visionary quality. Standing alone they lose much of their persuasive power because they do not have the support of the full article with its detailed substantiation.

Perhaps I should recapitulate what Professor tenBroek, as I see it, was attempting to do. He was trying to show by an exhaustive presentation of evidence that California has a dual system of family law, one law of the poor, distinct from the family law of the rest of the communitynot necessarily only the rich, but all those in a more comfortable position. ${ }^{5}$ Part of the significance of the study is its implication that other jurisdictions may have similar dual systems of law which regulate human conduct according to the class position of the participants. Yet by focusing on one jurisdiction, Cahifornia, tenBroek has been able to penetrate the subject in greater depth than could normally be attempted.

The result of this dual system of law, according to Professor tenBroek, appears to be a separating wall in regard to almost any matter of concern for the family - possession of property; support relations between husband, wife, and children; creation and dissolution of the family; custody of children; rights and duties of parents; and so on. In regard to the poor there appears to be less emphasis on rights, and fitness as a parent or even as a useful citizen is rarely presumed. The burden of proof is cast on the poor person, whatever the issue may be, to make a case in his favor. $\mathrm{He}$ is often subjected to official investigations, not infrequently to humiliation and harassment. ${ }^{7}$ His phight is subject to exploitation for political purposes, for instance, during elections, because of the public concern for the spending and possible waste of tax moneys. The law of the poor appears to be largely a creation of the legislature and, by way of implementation, of the executive. Regulations of government agencies play an important role, as do actual practices of welfare workers and police which are often characterized by low visibility. ${ }^{8}$

The family law of the more fortunate, following Professor tenBroek's reasoning, is largely created and administered by the courts. The law

\footnotetext{
4 tenBroek, 16 STAN. L. Rev. at 978, 17 Stan. L. Rev. at 623-24, 681-82.

' 5 tenBroek, 16 Stan. L. REv, at 258.

6 Emphasized throughout parts 2 and 3, 16 Stan. L. Rev. 900; 17 Stan. L. Rev. 614.

7 tenBroek, 17 Stan. L. REv. at 662-75. See also Reich, Midnight Welfare Searches and the Social Security Act, 72 YAIE I.J. 1347 (1963).

8 tenBroek, 17 Stan. L. Rev. at 614-17, 67\%. See also Goldstein, Police Discretion Not to Invoke the Criminal Process: Low-Visibility Decisions in the Administration of Justice, 69 YaLE L.J. 543 (1960). As a consequence of the present situation the poor frequently are forced to exhaust administrative remedies before they get to the courts.
} 
changes slowly here because of the conservative orientation of many judges, who are vested with substantial discretion. ${ }^{9}$ Marriage is viewed as similar to a partnership between semi-independent parties, resulting in a network of legal relations often proprietary in nature. ${ }^{10}$ The legislature appears to be basically uninterested. By contrast, the law of the poor is affected by continued tampering by the legislature and by pressure groups. It is a matter of persistent concern. Husband and wife are viewed as an integrated entity, having pooled resources for purposes of mimimizing public aid. ${ }^{11}$ Fiscal considerations are dominant and frequently enforced by conditions attached to welfare aid, designed to keep the costs of welfare programs low. The police power of the state appears to be used to secure the comfort and the wealth of those who are more fortunate against those who are in need and lack the time, power, and resources to pursue their legitimate aims. ${ }^{12}$ All these propositions are not merely stated, but heavily substantiated, and the sources have to be read in conjunction with the propositions.

Professor tenBroek concludes by advocating basic changes. Following Brown v. Board of Education ${ }^{13}$ he argues that separate treatment in respect to pubhic services cannot result in equality, regardless of whether the criterion is race or a discriminatory differentiation between the poor and the more affluent. Race and poverty should be treated similarly for purposes of constitutional law, ${ }^{14}$ especially since often the persons concerned are both members of ethnic minorities and indigent. tenBroek realizes that this is not necessarily the prevailing view of the moment, but he sees a hopeful trend because the problem of poverty is now discussed in terms of the fourteenth amendment's equal protection clause. ${ }^{15}$

Professors Lewis and Levy do not deny the existence of dual systems of law, but they try to make a case for them. Yet before I go into their

9 The discretion of the judges may be phrased in terms of a legal standard: for instance, "best interests of the child" and support "suitable to his circumstances." See tenBroek, 16 StAN. L. REv. at 915-27, 17 STAN. I. REV. at 646-48. Perhaps more important is the factual discretion which may result from the knowledge of trial judges that their decisions are not likely to be appealed. Even in case of appeal the parties have to overcome the reluctance of the higher courts to disturb the findings of judges "of first impression," who are viewed as being closer to the facts.

10 tenBroek, 17 Stan. L. REv. at 622-23.

11 Id. at 624-27.

$12 I d$. at 680 .

13347 U.S. 483 (1954). Other cases cited in support: Hardy v. United States, 375 U.S. 277 (1964); Gideon v. Wainwright, 372 U.S. 335 (1963); Griffin v. Illinois, 351 U.S. 12 (1956) ; Edwards v. California, 314 U.S. 160 (1941). See tenBroek, 16 STAv. L. Rev. at 258, 17 Stan. L. Rev. at 643-44, 681-82.

14 Referring to Mr. Justice Jackson in Edwards v. California, 314 U.S. 160, 184-85 (1941) (concurring opinion). See tenBroek, 17 STaN. L. Rev. at 681-82.

15 Id. at 681 . 
analysis it may be helpful to compare the methodology of Professor tenBroek with that of his critics.

Professor tenBroek cites numerous statutes, court opinions, regulations, and opinions of attorney generals in support of his propositions, down to unpublished minutes of welfare boards and the annual reports of local district attorneys. He further engages in a historical analysis that traces the present legal situation in California to the Elizabethan poor law system of the sixteenth and early seventeenth centuries. ${ }^{10}$ Throughout tenBroek's efforts one senses that he does not refer to law in the conventional way, distinguishing between the law and the facts. I am inclined to classify his work as empirical in nature, using legal references as data. Law appears as a fact, submitted in evidence for ultimate conclusions. ${ }^{17}$ Lewis and Levy in comparison are not so much empirically oriented in their essay; they approach their topic in an analytical fashion. I do not mean to establish an artificial dichotomy between empirical and analytical methods, but merely wish to point out a difference in emphasis. In any event, reading both articles in conjunction one gets the feeling that their methodologies are somewhat incongruent, a factor that may impair communication.

Professors Lewis and Levy admit duality in law as described, but they find it distracting to emphasize equal protection problems in this context. Duality is viewed by them as a common phenomenon that results from many legal classifications. Lewis and Levy point out by way of illustration that we differentiate those who are neghigent from those who accidentally injure others. ${ }^{18}$ We also have to differentiate those who are in need from those who are not. Inevitably we define the indigent in terms of income and available resources. Some conditions for the spending of public funds must be established, as long as this does not undermine the purposes of welfare programs. ${ }^{10}$ Lewis and Levy employ logical analysis to test the validity of the propositions that are put forward in tenBroek's article.

\footnotetext{
16 tenBroek, 16 STAN. L. REv. at 257, 900. A historical description of the English dual system of family disorganization is contained in Mueller, Inquiry Into the State of a Divorceless Society-Domestic Relations Law and Morals in England From 1660 to 1857, 18 U. PITT. L. REv. 545 (1957).

17 Cf. Oltvecrona, Law as Fact 16-27 (1939). See also Futrer, The Moratity of Law 150 (1964). Much useful empirical research can be conducted in ląw libraries: for example, content analyses of legal sources. The work of the legal historian can be viewed under this perspective too.

18 Lewis \& Levy, supra note 3, at 757. What has been said in regard to Professor tenBroek's work applies similarly here. The reasoning of Professors Lewis and Levy can only be appreciated and understood fully if one reads the article in its totality. An individual illustration loses inevitably some of its persuasiveness by being paraphrased and removed from the context.
}

19 Id. at $754-55,775$. 
The world of facts is touched upon in a fashion that stresses notions of evidence and prevailing mores. Nothing is inherently wrong with a dual system of law and the resulting differences in treatment provided that the state is not arbitrary. The burden of proof should be on the one claiming arbitrariness and a violation of constitutional mandates. ${ }^{20}$ Due regard should be given to legal policies in the light of commonly accepted notions of family life. Our society is built around the married family, and welfare programs are legitimately geared to this philosophy. ${ }^{21}$

Individual points are taken up by Professors Lewis and Levy to test the claimed arbitrariness of standards that may result in dual systems of family law and in a supposed inequality. If we had a proliferation of facts in tenBroek's article, we now face an imaginative effort to master the complexity of the problem by a point-by-point analysis. The authors introduce hypothetical situations to test whether there is discriminatory duality of substantive rules. Suppose that a particular jurisdiction has a rule that children who are financially able have to support their needy parents. ${ }^{22}$ The rule has a number of consequences; for instance, children of the wealthy do not have to support their parents but children of poor parents may face such a burden. On the other hand, poor children have no support obligations, contrary to children who are financially able. The authors conclude that even thougl there may be duality, it is based on rational factors and thus not in violation of the equal protection clause. Some difference in treatment, if rational, is unavoidable and even desirable.

Professors Lewis and Levy stress that we lack reliable data about the impact of law on people. As a consequence we may have to rely on numerous assumptions. ${ }^{23}$ Perhaps because of this difficulty the analysis is limited to stable family unions involving substitute parents. Should a stepfather or a "man in the house" be legally bound to support the children in the family, and should his financial status be considered in aid for dependent children programs? The answers given favor the prevailing legal situation.

Stepfathers are now immune from support obligations in most states, and legislators are unlikely to depart from ancient policies that the natural father is the one wlo should pay for his children. ${ }^{24}$ Lewis and Levy point out many uncertainties and variables. We do not know whether a prospective support obligation of stepfathers may deter them from marriage; we

20 Id. at 757,780 .

21 Id. at $757-59,765$.

22 Id. at 759-60.

23 Id. at 759, 764-65.

$24 I d$. at 762 . 
also do not know whether an exclusive support obligation of stepfathers promotes family cohesiveness. ${ }^{25} \mathrm{We}$ can hardly predict the consequences of a joint support obligation of both stepfathers and natural fathers, and we can only speculate on whether stepfathers who do not support their children would change their behavior under legal compulsion. However, since most stepfathers probably support the children in the family on a more or less voluntary basis, the status quo appears to be satisfactory. ${ }^{20}$ Additional reasons speak against imposing support obligations on "men in the house" who are not natural fathers. If they are natural fathers paternity actions under existing law can be brought against them. ${ }^{27}$

In regard to whether the earnings of stepfathers and "men in the house" should continue to be taken into account for welfare benefits, Professors Lewis and Levy similarly favor the prevailing legal situation. Legislators cannot be expected to adopt a welfare program that encourages stepfathers to rely on public support of their families. ${ }^{28}$ Furthermore, we do not know whether a substantial number of stepfather families with marginal income become unstable if welfare funds are withheld. In the absence of any reliable data we may prefer the prevailing practice which at least indirectly may encourage some financially able stepfathers to support their families. ${ }^{29}$ The same reasoning applies even more to the "man in the house." It is possible that he may leave the mother if welfare funds are withheld because of his presence. But we do not know whether the children are better or worse off without such a "father." In the absence of evidence to the contrary, the authors see no reason in any of these instances to abandon prevailing courses suggested by middle-class notions. ${ }^{30}$

In analyzing the case for or against a dual system of family law it appears to me that we have not so much a confrontation of empirical data and of logic, but one of underlying value preferences. Professor tenBroek seems to favor social change because of basic injustices, perhaps at the cost of experimentation. Professors Lewis and Levy favor a more cautious approach, at least for the time being, because of insufficient evidence on many important factors relating to the family. Both positions are intrinsically valid, provided one recognizes them as based on different value perspectives. Even in this respect I wish to submit a caveat. Sometimes one gets the impression that the authors are not really far apart. They agree that many basic injustices are inherent in the present welfare laws.

$25 I d$. at $764-66$.

$26 I d$. at $770-72$.

27 Id. at 772-74.

28 Id. at 775 .

29 Id. at 776-77.

$30 \mathrm{Id}$. at $777-80$. 
Sometimes their language is similar. When tenBroek stresses that "a new spirit in constitutional law has given positive signs of its future potential," ${ }^{331}$ and Lewis and Levy counter that "indigence is not yet the source of a right to demand benefits, supported by a correlative governmental duty to provide them,"32 one wonders whether at least some of the difference in opinion is related to a difference in style of thought.

A few reflections on the merits of the issue may be added. I tend to agree with Professor tenBroek that the present situation indicates sufficient evidence of damage. We need not go far. The Watts riots of August 1965 were a sudden and violent reaction against a felt injustice. The rioters of this Los Angeles Negro district directed themselves against police and social workers alike. Whether the riots were partly caused by inherent inequalities of dual systems of law or by failures of our welfare administration may be of minor concern. Similarly I consider the question academic whether the riots were caused by racial or economic factors, since it is hard to draw a distinction. Our law, as any legal system, to some extent has an ethnocentric orientation; in other words, it reflects and protects the value preferences of a dominant culture, ${ }^{33}$ and whether we classify this culture in terms of race or of economics does not seem to make much difference for our purposes. Those who set the standards tend to view them as of universal application, even though in many instances segments of the population, ethnic minorities and the poor, may live according to somewhat different standards of conduct and achievement. Thus many of the commonly used phrases, "disrespect for law and order," "failure to live up to responsibilities," "lacking motivation," "low morals

\footnotetext{
31 tenBroek, 17 Stan. L. Rev. at 681. (Emphasis added.)

32 Lewis \& Levy, supra note 3, at 754. (Emphasis added.) Professor Charles A. Reich has described how close we are to changes in policy. Reich, Individual Rights and Social Welfare: The Emerging Legal Issues, 74 Yare L.J. 1245 (1965); Reich, The New Property, 73 YALE L.J. 733 (1964).

33 I am trying to summarize here some of the thoughts contained in my essay, "Informal Marriage and Common Law Marriage," published in Sexual Behavior and the Law (Slovenko editor, 1965), at page 297, in particular under the heading "Impact of Caste and Class," pages 323-26. The permission of the editor, Professor Ralph Slovenko, and of the publisher, Charles C Thomas, is gratefully acknowledged.

Cultural factors may be eminently important in legal counseling and trial techniques, as I have suggested in Freenan, LeaA INTERVIEwINg and Counseling 126, 131-32 (1964).

It is generally conceded that dual systems of law exist in regard to Negroes and whites in the South. See Davis, Gardner \& Gardner, Deep South-A Soctal ANtmropologtcai Study of Caste and Class 483-538 (1941); Myrdal, AN American Difemara-The Negro Problem and Modern Dearocracy 523-69 (20th anniversary ed. 1962); Breaching the White Wall of Southern Justice, Time, April 15, 1966, p. 46. See also the statement of a high-ranking southern official: "The race prejudice is inherent in both races. The whites are the dominant race in this country, and of course control the handling of the prejudice." 1941-1942 FLA. Attornex Generar's BIENNIAI Rep. 332-33. This social phenomenon, unpleasant as it is, is probably not limited to the South and to Negroes. It may apply in similar fashion to the poor and other outgroups.
} 
and intelligence," may reflect ethnic preferences denying recognition to standards and conditions of living that vary from accepted norms.

The situation may at times acquire explosive elements because the deviating groups, even though heterogeneous in their make-up, are larger than commonly assumed. If one combines criteria of low income, low educational level, and substandard housing, about one-fourth to one-third of the total American population may be involved. ${ }^{34}$ Furthermore, poverty and low social status do not necessarily coincide. Some members of ethnic minorities may be comfortably situated, yet share a sense of deprivation with the poor. Teamsters and longshoremen may have higher incomes than white-collar workers, yet the history of their labor organizations seems to indicate shared identifications with some outgroups. One also may consider segments of the American youth who, even though of middle-class origin, sometimes sympathize with the ways of the deprived and the poor. Add those who are marginal for other reasons or who are indifferent, and it may become somewhat speculative whether the prevailing mores are as stable and secure as assumed. A certain amount of sociolegal experimentation may be desirable even from the perspective of those who want to preserve our middle-class values.

On the other hand, the War on Poverty could conceivably have negative aspects if it were to evolve into a "war on poor people." Professor tenBroek points out the damaging effects that some past social crusades have had, ${ }^{35}$ and Professors Lewis and Levy seem to feel that it is sometimes wise to permit lower-class families to resolve their problems by selfhelp under their own standards of conduct. ${ }^{36}$ In this broader sense perhaps a case can be made for a dual system of law. However, we may have to

34 According to the United States Census $30.9 \%$ of all American families had an annual income of less than $\$ 4,000$ in $1959 ; 39,500,000$ persons twenty-five years old and over did not go beyond the eighth grade of formal education in 1960; $26 \%$ of all housing units in the United States were deteriorating, dilapidated, or lacking plumbing facilities in 1960. Bureau of the Census, U.S. Dep'r of Comagerce, Statistical Abstract of the United STATES $117,333,759$ (83d ed. 1962).

Other estimates: Thirty-two million Americans bive on the outskirts of poverty, 109 Cong. Rec. 172 (1963) (State of the Union Message of President Kennedy); thirty-two to forty-five million citizens suffering from serious economic and social handicaps, 109 Conc. REc. 6452 (1963) (remarks of Senator Williams of New Jersey to the National Service Corps Act); forty to fifty million citizens live in poverty, HarrIngton, THE OTHER AMErucaPoverTy IN THE UNited StaTes 1, 175-91 (1962).

A recent Bureau of the Census study of South Los Angeles shows a decliming purchasing power of the typical family and a sharp increase in the proportion of deteriorating and dilapidated housing units in the five years preceding the Watts riots. See 1960-65 Survey-A Study of the Decline of Watts, San Francisco Chronicle, March 9, 1966, p. 6, col. 1.

${ }^{35}$ See authorities cited in note 7 supra. See also Alves, Confidentialtry IN Soctal WORK 87-90 (1959).

${ }^{36}$ Lewis \& Levy, supra note 3 , at 774. 
expand our definition of law for this purpose. Law should perhaps embody the normative behavior within the subcultures in question. The poor have created among themselves a law of their own. The family organization developed among the lower classes has elements conducive to social health ${ }^{37}$ Even though the practices do not necessarily conform to prevailing mores, they have assured survival under adverse circumstances.

In spite of its ethnocentric characteristics, our legal system has always recognized outgroup standards to some extent, often without openly admitting such recognition. Informal marriages, which frequently occur in the lower classes and ethnic minorities, have been sustained under theories of common law marriage, marriage by estoppel, prescription or ratification, putative marriage, de facto marriage, and so on. Not yet fully explored is the extent procedural devices have been used to reach substantive results: for instance, by application of presumptions of marriage in cases of prolonged cohabitation, or presumptions of nomarriage or of divorce in cases of factual marriage breakup..$^{38}$ Professors Lewis and Levy have validly suggested that it may be a good policy to permit couples who have entered into an informal marriage to terminate their relationship in the same informal fashion. ${ }^{39}$ In many instances the normative behavior of the poor has been recognized by way of executive toleration, even though it is technically in violation of some legal prescription. These various methods result in a dual system of law that may have some positive aspects.

This comment cannot exhaust the full range of problems that are posed by dual systems of law. Whenever there is duality in law, we may have the possibility of conflicts, with all the legal implications. We may rethmk the basic issues under the perspectives of systems science and operations research. A body of knowledge has been accumulated under these headings that may furnish novel insights. A systems approách was successfully applied during World War II in England and later on in the

37 Myrdal, op. cit. supra note 33, at 930-35. Professor Herma Hill Kay and Doctor Irving Phillips note that positive factors are easily overlooked because of the differences in class attitudes toward parental competence. Kay \& Phillips, Poverty and the Law of Child Custody, 54 CALIF. L. Rev. 717, 736-37 (1966).

On a more general level it is maintained by the Moynihan Report that the matricentric structure of the lower-class Negro family and the resulting dual system of family organization have been harmful: "[I]t is clearly a disadvantage for a minority group to be operating on one principle, while the great majority of the population, and the one with the most advantages to begin with, is operating on another." Office of Policy PIAnndng and REsearch, U.S. Dep't of Labor, The Negro Famerty-The Case for Nattonal Action 29 (1965).

38 I have described this in greater detail in my essay on informal marriage, supra note 33, at 318-23.

${ }^{39}$ Lewis \& Levy, supra note 3 , at 774 n.67. 
United States to deal with military emergencies. After the War it proved to be useful in an industrial context. More recent developments concern the improvement of large-scale social systems. ${ }^{40}$

By independent inquiry, systems scientists have come close to the problems of dual systems of law, as can be seen from the following passage in Professor C. West Churchman's writings:

Finally, when we come to social welfare, it is easy enough to point out that many of our policies simply attack the dignity of the human being by forcing him to comply with many kinds of regulations in order to attain support from society. If he claims support he is always subject to investigation because, according to those in power, many people try to claim support who do not deserve it. Compliance with the regulations forced by the state make the recipient of social welfare virtually admit that he is a less than adequate member of society. ${ }^{41}$

Needless to say that much current study in systems science is carried on without the benefit of legal consultants, just as legal research does not have the benefits of operations research. It is conceivable that a shift in emphasis stressing aspects of systems theory may be helpful in legal planning.

Another line of inquiry that can only be touched upon relates to double standards of morality. I realize that dual systems of law and double standards of morality do not fully coincide. Yet Professor tenBroek's article seems to bring double standards of this kind to our attention, because law supposedly is of universal quality, while in fact differentiations are made on the basis of economic conditions, ethnic factors, and so on. Even in regard to double standards of morality the problems appear to be complex. Eminent authorities have defended cultural patterns that result in

40 See Churcharen, On the Etrics of Large-Scate Systems, Part I (Space Sciences Laboratory, University of California, Berkeley, Internal Working Paper No. 37, 1965); Hoos, The Appitcation of Systears Anarysts to Soctal Problems: The Carmorna Expertence (Space Sciences Laboratory, University of California, Berkeley, Internal Working Paper No. 32, 1965); 1 National Cosmo's on Technology, Automation, and Economic Prggress, Report, TECHNOLOGY AND THE AMERTCAN ECONOMY 95-108 (1966); see also CHURCHMAN, ACKOFF \& ARNOFF, INTRODUCTION to Operations REsEarch (1957).

The California studies referred to by Hoos have resulted in four reports-AEROJETGenerat Corp., Calffornta Waste Management Study-A Report to the State of Cartfornia Departanent of Public Heatth (1965); Lockheed Missines \& Space Co.,

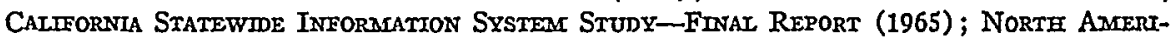
can aviation, Inc., CaIffornla Intrgarated Transportation Study (1965); and SpaceGeneral Corp., A Study of Prevention and Control os Crmme and Deuinquencx-Final RaporT (1965). Perhaps the problem is now whether knowledge accumulated by the military and industry can be transferred to a social context.

41 Churchaman, ON the Ethics of Large-Scale Systems, Part I, ch. IV, at 6-7 (Space Sciences Laboratory, University of Cahifornia, Berkeley, Internal Working Paper No. 37, 1965). 
double standards. Margaret Mead has described valuable incidents of our perennial failure to live up to standards that perhaps are set too high.42 Gustav Radbruch has expressed a similar thought in startling fashion. Double standards of morality, he has said, are characteristic of middleclass cultures, and they should not be viewed as inherently evil. They presuppose and are naturally allied to even stronger moral demands and commitments. ${ }^{43} \mathrm{Be}$ that as it may, the effectiveness of moral double standards probably depends somewhat on people being essentially unaware of them. When a double standard is articulated and thus brought to our attention, exposed as it were, it may become difficult to retain.

\footnotetext{
42 Mead, ANd Keep Your Powder Dry-AN ANThropologist Looks at AMarica 10-11, 126-37 (new expanded ed. 1965).

43 RadBruch, Der Geist des englischen Rechis 12-13 (3d ed. 1956): "Feigned moralIty, if it is to make any sense, presupposes in a people an even stronger measure of genuine moral demands and commitments. The degree of hypocrisy is the best measure for the power of morality over a people." (This author's translation from the German langnage.)
} 